appreciable influence in this direction. Failing further progress in this field, magnesium alloys will probably have to be protected against severe corrosive conditions by paints applied over some chemically produced film, without which paints will not adhere satisfactorily. Special reference is made to the selenium and to the chromate treatment for the production of protective films as a basis for painting, and it is pointed out that the choice of paint to put on the films is important, as many pigments suitable for iron and steel actually stimulate corrosion on magnesium alloys. Reference is also made to the corrosive action of 'leaded' motor and aviation fuels on magnesium cylinders. It is stated that work at the Chemical Research Laboratory has shown that the addition of 1 per cent of quinoline to the fuel inhibits this action and exerts no harmful effect in its anti-knock properties.

Owing to the ease with which molten magnesium and its alloys combine with oxygen, special methods have to be employed for melting and casting. With the methods described in the monograph, however, it is stated that there is no difficulty in producing castings in magnesium alloys either in sand or permanent moulds.

The monograph summarizes the mechanical properties at room temperatures of the magnesium alloys at present used in industry. These are almost entirely confined to alloys with aluminium and zinc, of ten containing a small amount of manganese introduced to improve the corrosion-resisting properties. With alloys containing 8 per cent or more of aluminium, it is usually possible to produce increased hardness and a general improvement in properties by suitable heat treatment. This takes the form of exposure to a temperature of $420^{\circ} \mathrm{C}$. for a few hours, sometimes followed by tempering for 4-7 days at about $150^{\circ} \mathrm{C}$. Increased ductility can be produced by adding cadmium, and reference is made to an alloy consisting of aluminium, silver, manganese and calcium, which has been found suitable for use in stressed parts at room temperature.

A number of possible uses of magnesium alloys involve the exposure of the metal to elevated tem. peratures, and for this reason their mechanical properties when hot become important. The results of tests up to $300^{\circ} \mathrm{C}$. are given for various alloys. Silver, it has been found, increases the ultimate strength of magnesium up to $290^{\circ} \mathrm{C}$. but its effect when used alone is not so marked as that of aluminium. Recently cerium has been added, which is stated to have a pronounced effect in increasing the strength of magnesium at elevated temperatures. Even small quantities, of the order of 1 per cent, have a remarkable effect in increasing the hardness at $300^{\circ} \mathrm{C}$. The addition of a small amount of calcium to the cerium-magnesium alloys is beneficial in preventing oxidation during melting and heat treatment as well as in improving the age-hardening properties. The increased hardness due to heat treatment is, however, relatively small, even when calcium is present.

A harder alloy can be produced by adding nickel to the cerium-magnesium alloys, but such alloys were found to be very liable to corrosion. This can be reduced slightly by replacing nickel by cobalt and manganese.

The final chapter of the monograph contains reproductions of all known constitution-temperature diagrams for the alloys of magnesium in the form considered by the authors to be most nearly correct. F. C. T.

\title{
Conditions in the Special Areas of Great Britain
}

$\mathrm{S}^{\mathrm{ni}}$ IR GEORGE GILLETT'S admirable first report as Commissioner for the Special Areas of England and Wales, covering the year ended Septem. ber 30, 1937, shows no departure from the example of frankness and independence of judgment that was set by Sir Malcolm Stewart. The report is indeed in striking contrast to the evidence tendered by the Board of Trade to the Royal Commission on the Geographical Distribution of the Industrial Popula. tion. Like Sir Malcolm Stewart, Sir George Gillett stoutly upholds the principle that the State should control the location of industry, asserting that the introduction of tariffs and quotas has enhanced the Government's responsibility in this matter, and that social and strategic as well as economic causes are driving the Government to abandon the old laissezfaire attitude. The recommendations in the recent report of the Import Duties Advisory Committee on the present position and future development of the iron and steel industry, no less than the appointment of the Royal Commission, illustrate this tendency.

The first recommendation is that the conclusions of the British Iron and Steel Federation in regard to all schemes of development of the industry should, whether favourable or not, be reported to an independent body looking to the general public interest.
This independent body is to be the Import Duties Advisory Committee itself, and Sir George Gillett points out that this recognition that matters which concern the welfare of thousands of our fellow citizens are properly to be considered in relation to their social and broad economic consequences, as well as in relation to the profit and loss account of the individual concern, marks a great advance.

The second recommendation to which Sir George directs attention relates to the need for dealing with the problem of restoration on a systematic and comprehensive scale to avoid the serious risk of creating extensive areas of broken and barren land by quarrying ironstone over large new areas. Sir George Gillett considers that this touches on one of the vital problems of the Special Areas, and that the recommendations should be extended to apply to all industries, such as the coal, chemical and brick industries, which are apt to leave scars on the landscape, and he suggests that the tragic relics of the past should be avoided by a system of compulsory insurance or by putting responsibility for clearance on the industry as a whole.

As Sir George Gillett points out, the ideal solution is for new industries to be established on sites which have already been scarred and spoilt for any but industrial purposes, as in the huge new steel works 
being erected by Richard Thomas and Co. on the site of the old works at Ebbw Vale and the new steel works to be erected on the site of the old works at Palmer's Yard in Jarrow. These examples in themselves sufficiently indicate one way in which the problems of the Special Areas are linked up with those of the preservation of amenities generally, but the North Eastern Trading Estate at Team Valley provides a conspicuous example of the way in which industrial development in a new area can be planned so as to add to, rather than detract from, the amenities of the district. Already it appears that proper facilities for manufacture, pleasant conditions for labour and the high advertising value of a wellplanned estate weigh quite as heavily with industrialists as economic considerations. Even if the proximity of a fine type of labour has been a further factor, there is still evidence of a real desire on the part of many industrialists to assist in the solution of the problems of this particular Area.

The Commissioner in his report does not hide the difficulties that remain to be overcome or the seriousness of the present situation, but the keynote of the present report is a definite but restrained optimism. During the twelve months, unemployment in the Areas has fallen by $25 \cdot 6$ per cent., of which only a comparatively small part was due to transference out of the Areas, the corresponding figure for the rest of England and Wales being $12 \cdot 0$ per cent. National and international causes have undoubtedly been responsible for most of this improvement, but it has been largely independent of armament work. Another encouraging sign of progress in the Durham and Tyneside Special Area, for example, is the extent to which much of the work necessary for the recuperation of the Area is now in the hands of bodies locally administered and having a lease of life which is independent of Special Area legislation. Further reduction in the volume of unemployment depends upon the success of the measures now being adopted to induce new industries to establish themselves, the further development of those measures and the policy of the Royal Commission.

As regards particular measures, the report refers once more to the question of establishing a calcium carbide factory in South Wales, the investigation of schemes for low-temperature carbonization or hydro. genation of coal, the improvement of communications, and the research carried out by the Technical Advisory Committee of the North East Development Board, while the Commissioner for the Special Areas in Scotland lays a good deal of stress upon the utilization of coke-oven gas as well as the establishment in the Area of one or other processes for the extraction of oil from coal, if any impression is to be made on the most intractable problem-that of continuing unemployment in the coal industry.

For the future, Sir George Gillett insists that it is not so much new organizations that are wanted as twelve months of steady work to see if, with the powers already granted, any impression can be made on the 200,000 unemployed men and women still left in these Areas, of whom about 80,000 are men of forty-five years of age and upwards, many suffering from diseases contracted through working in the coal mines. This is the most significant problem of the Areas, and is being tackled in various ways, apart from insisting on the employment of older men in wage-paid schemes, such as group holdings, subsistence production, voluntary (local amenities) schemes and allotments.
The problem of the Scottish Special Areas is essentially different in the greater difficulty of transference, in the absence of an expanding industrial centre in Scotland, and in the lesser severity of unem. ployment statistically. There are, however, many towns and communities with every local service, labour suitable for training and employment, attrac. tive amenities, and a robust civic and social sense. Measures to deal with the unemployment in the coal industry have already been mentioned. Among indirect measures, the Commissioner lays stress on housing, land settlement and assistance to schemes for improving water supplies, sewerage and sewage disposal, drainage and the like.

In conclusion, in view of significant omissions in a recent book on the Special Areas, it is pertinent 16 point out that the present reports indicate that, up to September 30,1937 , estimated commitments, including expenditure on the Special Areas Fund, amount to $£ 12,900,000$ in England and Wales and $£ 2,488,584$ in Scotland.

\section{Science News a Century Ago}

\section{Progress of British Railways}

IN the January number of the Civil Engineer and Architects' Journal, under the heading "Progress of Railways", were given extracts from various news. papers referring to the state of construction, growth of traffic, etc., on some fifteen railways. Of the Eastern Counties Railway, it was said : "The works of this railway are now pushed as far as Ilford and it is confidently expected that it will be opened to that town (seven miles) next summer." As regards the Grand Junction Railway, it was remarked : "It is said that the Post Office Department have concluded a valid agreement with the Directors, which will enable the inhabitants of Liverpool after the first of May next, to receive their London letters, dispatched on the preceding evening, at eight on the following morning"; and also that "Notice has been given, that it is intended to dispatch a train from the station at Lime street, for the conveyance of pigs to Birmingham". Similar trains were to be dispatched each Tuesday, Wednesday and Thursday. On the Whitby and Pickering line, "A great increase has taken place in the tonnage amount of traffic and numbers of passengers conveyed, the increase in the number of passengers during the half-year had been 8,000 , and the increase in goods traffic 6,000 tons". Another notice said, "On the lst of January, the London and Birmingham Railway will be open as far as Stony Stratford, and also the Birmingham end as far as Rugby, making in the whole 77 miles of this great undertaking completed." The Bolton and Preston Railway had been decided upon, while at a meeting at Penrith of the promoters of the Lancaster and Glasgow Railway, one speaker, when alluding to the western line over Morecambe Bay to Whitehaven, declared that Mr. Stephenson had made a mistake of fourteen miles in computing the length of the line !

\section{Visions of the Extension of the Electric Telegraph}

ON January 5, 1838, a correspondent "Inquisitivus" wrote to the editor of the Mechanics' Magazine about the electric telegraph, which was then engaging much attention. "It is too often the case", he said, "that 